\section{Commentary: Deep hypothermic circulatory arrest for left chest aneurysm repair: Ready for prime time?}

\section{Nicholas T. Kouchoukos, MD}

Deep hypothermic circulatory arrest (DHCA) as an adjunct during cardiovascular surgical procedures has a long history, beginning in the early 1950s. ${ }^{1}$ In 1964, Borst and colleagues ${ }^{2}$ first reported the successful use of DHCA through a left thoracotomy to repair an arteriovenous fistula of the aortic arch. Although DHCA is currently widely applied for management of aneurysms and dissections involving the aortic arch, there has been less enthusiasm for its use in the management of aortic disease that involves a lateral approach. In many experienced centers that perform open repair of descending thoracic and thoracoabdominal aortic disease, DHCA is generally reserved for situations in which aortic clamping is impossible or inadvisable or in which repair of the distal aortic arch is also required, and its use is often unplanned. In these circumstances, the use of DHCA has been associated with substantial mortality and morbidity. ${ }^{3-5}$ As a consequence, it has been used infrequently, and left heart bypass or partial cardiopulmonary bypass with mild hypothermia remain the most widely used techniques for circulatory support when a lateral approach is required.

In this issue of the Journal, Alhussaini and colleagues ${ }^{6}$ report their experience using DHCA in 46 patients undergoing repair of descending thoracic (DTA) or thoracoabdominal (TAAA) aortic disease, and compare the outcomes with those of 38 patients in whom cardiopulmonary bypass and permissive hypothermia were used. The 2 groups were comparable in terms of most of the baseline characteristics but differed substantially in the need for distal aortic arch

\footnotetext{
From the Division of Cardiovascular and Thoracic Surgery, Missouri Baptist Medical Center, BJC Healthcare, St. Louis, Mo.

Disclosures: The author reported no conflicts of interest.

The Journal policy requires editors and reviewers to disclose conflicts of interest and to decline handling or reviewing manuscripts for which they may have a conflict of interest. The editors and reviewers of this article have no conflicts of interest.

Received for publication April 8, 2021; revisions received April 8, 2021; accepted for publication April 9, 2021; available ahead of print April 16, 2021.

Address for reprints: Nicholas T. Kouchoukos, MD, Division of Cardiovascular and Thoracic Surgery, Missouri Baptist Medical Center, BJC Healthcare, 3023 N Ballas Rd, Suite 150D, St. Louis, MO 63131 (E-mail: ntkouch@aol.com).

J Thorac Cardiovasc Surg 2023;165:1283-4

$0022-5223 / \$ 36.00$

Copyright (C) 2021 by The American Association for Thoracic Surgery

https://doi.org/10.1016/j.jtcvs.2021.04.022
}

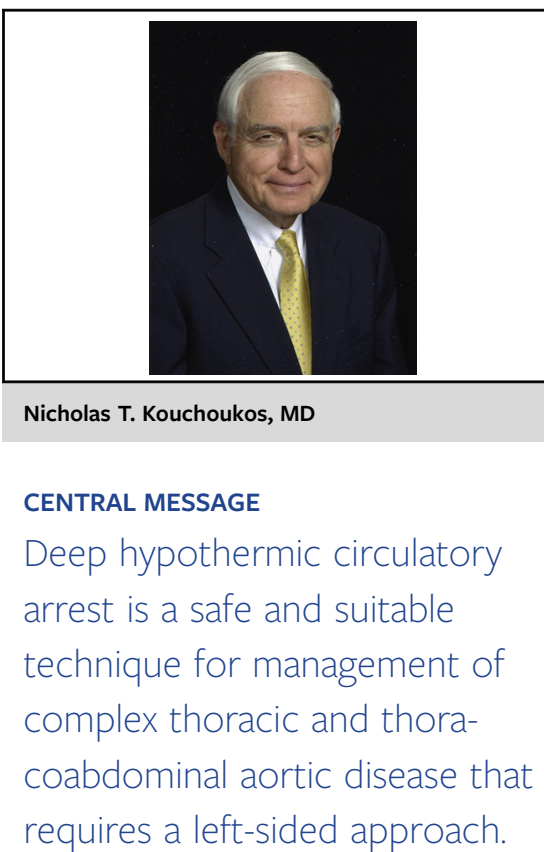

replacement (only in the DHCA group), and a higher prevalence of chronic aortic dissection and previous aortic repair and a lower prevalence of Crawford extent I TAAA disease in the DHCA group. As would be expected, the durations of cardiopulmonary bypass and total operative time were greater in the DHCA group. Despite the differences between the 2 groups, there were no statistically significant differences in the prevalence of early mortality, stroke, permanent spinal cord injury, permanent renal failure necessitating hemodialysis, reoperation for bleeding, or freedom from major adverse outcomes. Data on transfusion of blood products were not provided.

Although this is not a truly comparative study, it adds to the growing body of knowledge regarding the safety and utility of DHCA for the management of aortic disease requiring a left-sided approach. Several single-institution studies using propensity matching and a meta-analysis comparing DHCA and left heart bypass have shown comparable outcomes with regard to early mortality and major morbidity. ${ }^{7-10}$ Two of those studies demonstrated better preservation of renal, hepatic, and spinal cord function with DHCA. ${ }^{7,8}$ Studies from 2 centers of patients with DTA and TAAA aortic disease in which DHCA was used as the sole method of organ protection showed rates of spinal cord ischemic injury and renal failure among the lowest reported in the literature, especially in the higher-risk subsets. ${ }^{11-13}$ Little published information is available on the volume of homologous blood products and hemostatic agents infused with the 2 techniques; however, in a study of 90 propensity-matched 
patients reported by Weiss and colleagues, ${ }^{7}$ there was no statistically significant difference in the volume of blood products administered (red cells, platelets, and fresh-frozen plasma) between the DHCA and non-DHCA patients.

The foregoing findings suggest that there may be a greater role for the use of DHCA when a lateral approach is required to treat DTA and TAAA aortic disease. Given the increased use of endovascular grafting to treat these conditions, as noted by Aljussaini and colleagues ${ }^{6}$ and by others, cases presenting for open repair will remain complex and challenging. When applied routinely, DHCA is a safe and highly satisfactory technique for managing patients with these conditions, and it likely will be used with increasing frequency in the future.

\section{References}

1. Kouchoukos NT, Scharff JR. History of cardiac surgery. In: STS cardiothoracic surgery E-book. Available at: https://www.sts.org. Accessed April 20, 2021.

2. Borst HG, Schaudig A, Rudolph W. Arteriovenous fistula of the aortic arch: repair during deep hypothermia and circulatory arrest. I Thorac Cardiovasc Surg. 1964;48:443-7.

3. Safi HJ, Miller CC III, Subramaniam MH, Campbell MP, Iliopoulos DC, O'Donnell JJ, et al. Thoracic and thoracoabdominal aortic aneurysm repair using cardiopulmonary bypass, profound hypothermia, and circulatory arrest via left side of the chest incision. J Vasc Surg. 1998;28:591-8.

4. Coselli JS, Bozinovski J, Cheung C. Hypothermic circulatory arrest: safety and efficacy in the operative treatment of descending and thoracoabdominal aortic aneurysms. Ann Thorac Surg. 2008;85:956-63; discussion 964.
5. Yoo JS, Kim JB, Joo Y, Lee WY, Jung SH, Choo SJ, et al. Deep hypothermic circulatory arrest versus non-deep hypothermic beating heart strategy in descending thoracic or thoracoabdominal aortic surgery. Eur J Cardiothorac Surg. 2014;46: 678-84.

6. Alhussaini M, Falasa MP, Jeng EI, Martin T, Becker TK, Arnaoutakis GJ, et al. Application of deep hypothermic circulatory arrest in open left chest aortic aneurysm repair. J Thorac Cardiovasc Surg. 2023;165:1275-80.

7. Weiss AJ, Lin HM, Bischoff MS, Scheumann J, Lazala R, Griepp RB, et al. A propensity score-matched comparison of deep versus mild hypothermia during thoracoabdominal aortic surgery. J Thorac Cardiovasc Surg. 2012;143: 186-93.

8. Yoo JS, Kim JB, Jung SH, Choo SJ, Chung CH, Lee JW. Surgical repair of descending thoracic and thoracoabdominal aortic aneurysm involving the distal arch: open proximal anastomosis under deep hypothermia versus arch clamping technique. J Thorac Cardiovasc Surg. 2014;148: 2101-7.

9. Wahlgren CM, Blohmé L, Günther A, Nilsson L, Olsson C. Outcomes of left heart bypass versus circulatory arrest in elective open surgical descending and thoraco-abdominal aortic repair. Eur J Vasc Endovasc Surg. 2017;53: 672-8.

10. Papadimas E, Tan YK, Qi Q, Ng JJ, Kofidis T, Teoh K, et al. Left heart bypass versus circulatory arrest for open repair of thoracoabdominal aortic pathologies. ANZ J Surg. 2020;90:2434-40.

11. Kouchoukos NT, Masetti P, Rokkas CK, Murphy SM. Hypothermic cardiopulmonary bypass and circulatory arrest for operations on the descending thoracic and thoracoabdominal aorta. Ann Thorac Surg. 2002;74:S1885-7; discussion S1892-8.

12. Fehrenbacher JW, Siderys H, Terry C, Kuhn J, Corvera JS. Early and late results of descending thoracic and thoracoabdominal aortic aneurysm open repair with deep hypothermia and circulatory arrest. J Thorac Cardiovasc Surg. 2010;140: S154-60; discussion S185-90.

13. Kouchoukos NT, Kulik A, Haynes M, Castner CF. Early outcomes after thoracoabdominal aortic aneurysm repair with hypothermic circulatory arrest. Ann Thorac Surg. 2019;108:1338-43. 